\title{
A Parliament of Novels: the Politics of Scottish Fiction 1979-1999
}

Un parlement dans la littérature : politique et fiction écossaise 1979-1999

\section{David Leishman}

\section{(2) OpenEdition} Journals

Electronic version

URL: http://journals.openedition.org/rfcb/1175

DOI: $10.4000 /$ rfcb. 1175

ISSN: 2429-4373

\section{Publisher}

CRECIB - Centre de recherche et d'études en civilisation britannique

\section{Printed version}

Date of publication: 2 January 2006

Number of pages: $123-136$

ISBN: 2-911580-23-0

ISSN: 0248-9015

\section{Electronic reference}

David Leishman, «A Parliament of Novels: the Politics of Scottish Fiction 1979-1999 », Revue Française de Civilisation Britannique [Online], XIV-1 | 2006, Online since 15 October 2016, connection on 02 May 2019. URL : http://journals.openedition.org/rfcb/1175; DOI : 10.4000/rfcb.1175

\section{(c) (i) $\ominus$}

Revue française de civilisation britannique est mis à disposition selon les termes de la licence Creative Commons Attribution - Pas d'Utilisation Commerciale - Pas de Modification 4.0 International. 


\title{
A Parliament of Novels : the Politics of Scottish Fiction 1979-1999
}

\author{
David LEISHMAN \\ Université de Grenoble 3
}

The Scottish literary scene enjoyed so great a resurgence at the end of the $20^{\text {th }}$ century that the period has sometimes been termed the second Scottish renaissance. ${ }^{1}$ After a period of relative moroseness, initially exacerbated by the 1979 referendum result, ${ }^{2}$ Scottish fiction found a new vitality which can be charted by a number of factors: the strong growth in the number of new novels published; ${ }^{3}$ the linguistic, narratological and typographic experimentation of authors such as Alasdair Gray, James Kelman or Janice Galloway; the increased critical interest in Scottish letters; the commercial success of authors such as Ian Rankin or Irvine Welsh, who, despite their international popularity, remain distinctively Scottish in terms of orientation or voice.

By the 1970s there already existed an important network of peer support and encouragement in Scotland, as exemplified by the seminal writers' group run by Philip Hobsbaum at Glasgow University, which had already brought together Kelman, Gray and the poet Tom Leonard (leading to talk of a so-called Glasgow School). Once established, such authors often tended to use their reputation to champion the next generation of authors, as in the case of James Kelman's support for the novelist Jeff Torrington, or Janice Galloway's publishing, as the guest editor of New Writing Scotland no.9, of the first extracts of what would later be published as the novel Trainspotting. ${ }^{4}$ Even though by the mid nineties many of the most successful Scottish authors had been signed by large, international publishers, the existence of small, independent Scottish publishing houses such as Polygon (formerly part of Edinburgh University Press), Canongate, Rebel Inc. or Clocktower Press (founded by the authors James Meek and Duncan McLean) also contributed to the flourishing national scene by publishing the new work of up-and-coming authors such as Irvine Welsh, James

\footnotetext{
${ }^{1}$ Philip Hobsbaum, often cited as the origin of this phrase, is more circumspect, mentioning only 'the second revival of Scottish Literature this century'. Philip HOBSBAUM, 'Speech rather than Lallans: West of Scotland Poetry', Lines Review, n¹13, June 1990, p. 7.

${ }^{2}$ Douglas Gifford speaks of 'the real dreich aftermath of the failure of devolution'. Douglas GIFFORD, 'Scottish Fiction 1980-1981: The Importance of Alasdair Gray's Lanark', Studies in Scottish Literature, vol. XVIII, 1983, p. 210. See also Cairns CRAIG, Out of History, Edinburgh: Polygon, 1996, p. 105.

${ }^{3}$ Based on the information in Alison LUMSDEN, 'The Scottish novel since 1970: a bibliography', pp. 232-243 in: Gavin WALLACE \& Randall STEVENSON (eds.), The Scottish Novel Since the Seventies (1993), Edinburgh: Edinburgh University Press, 1994.

${ }^{4}$ Claire SQUIRES, 'Trainspotting and Publishing, or Converting the Smack into Hard Cash', Edinburgh Review, n¹01, 1999, p. 52.
} 
Meek or Alan Warner. ${ }^{5}$ In poetry, theatre, comedy or popular music, Scottish literature's vigour was matched by that of other fields of Scottish culture.

Yet, at the same period, the political and economic context was marked by a bleakness which was entirely at odds with this obstinate good health. Faced with such a paradox, one must not imagine that Scottish writing flourished at this time only by becoming detached from the country's socioeconomic concerns. On the contrary, many commentators ${ }^{6}$ have remarked that one defining characteristic of contemporary Scottish fiction is its ceaseless investigation of what has, somewhat reductively, been termed the 'gritty realities of urban Scotland'. ${ }^{7}$ Indeed, Scottish fiction can be seen as resolutely disputing the notion of a pure literature existing beyond politics and economics, and thus divorced from the mean concerns of everyday existence. The desire for a literature which reconnects with the voices and material existence of society's less exalted orders - from its school teachers, shop workers and bus conductors, to its jobless, vagrants and drug addicts - has meant that Scottish writing has occasionally retained an otherwise unfashionable preoccupation with literary realism. The focus, even in its more experimental modes, has indeed often been grimly urban and post-industrial, not merely reflecting the existence of Scotland's Central Belt majority, but also providing a welcome counterbalance against the anhistoricism conveyed by the romantic tourist myths of pre-modern wilderness and purity. By pointing repeatedly to the here and now, Scottish fiction does not deny the past but reclaims a truer sense of history, where inexorable contemporaneity and human agency replace any essentialist notions of Scottishness as a cultural or biological given.

The socio-political context remains ever important in a Scottish literature which shows itself, by its recurring thematic concerns - linguistic oppression, constitutional dissatisfaction, the destabilising effects of rapid deindustrialisation, the alienation that accompanies modern capitalism - to be painfully aware of the context of its production. For many works, this distinctive Scottish context is merely the means by which authors impudently presuppose the validity of their own national and personal experience, although in a smaller number of works a shriller tone or a firmer ideological orientation is sometimes taken. Nevertheless, particularly at a time when the questions of national identity and political representation were so fraught, it can be argued that all works of Scottish fiction inevitably take a stance on such questions, whether voluntarily or not. This can also be true for those which, at first sight, appear to belie any form of political or national engagement.

The inter-penetration of literature and politics is readily accepted by many Scottish authors whose activism at the heart of a "culture of dissidence, ${ }^{8}$ has led

\footnotetext{
${ }^{5}$ See Peter Kravitz's introduction, p. xvii in : Peter KRAVITZ (ed.), The Picador Book of Contemporary Scottish Fiction (1997), London: Picador, 1998.

${ }^{6}$ See Keith DIXON, 'Writers into battle: political dissent among contemporary Scottish writers', Etudes écossaises, Hors Série, 1994, p. 165.

${ }^{7}$ T.M. DEVINE, The Scottish Nation 1700-2000 (1999), London: Penguin Books, 2000, p. 608.

${ }^{8}$ Liz HERON, 'La « scotticité » de Walter Scott à Alasdair Gray’, Liber, n²4, October 1995,

p. 17. For a complete study of the phenomenon, see Keith DIXON, 'Notes from the
} 
them to become involved in issues as varied as closures in the steel industry (William McIlvanney), racist attacks and asbestosis (James Kelman), or Scottish independence (Alasdair Gray being notably the author of a pro-Independence pamphlet, Why Scots Should Rule Scotland). ${ }^{9}$ Such militancy points to the strong leftwing orientation of many Scottish writers of the second renaissance, ${ }^{10}$ which has led some commentators to complain of a new hegemony that crowds out middle class, pro-Union, anglicised perspectives. ${ }^{11}$ The broadly socialist views of the majority of authors tend indeed to coincide with a general, non-overtly politicised support for the specificities of Scottish linguistic expression, culture and experience. Taken together, these factors combined in the 1980s and 1990s to create a cultural consensus distinct from that of mainstream Anglo-British society which, in four successive elections, cautioned the Thatcherite revolution and the Conservative Party's defence of a strong, unified British state.

This study seeks to briefly chart the manner in which Scottish fiction interacted with the socio-political sphere at this time. The premise is not that literature functions as the mirror of society, but that all literature, inescapably ideological, can only be fully comprehended by situating its semantic, lexical and narrative choices against the dominant discourses of the context of its production. ${ }^{12}$ This approach is particularly significant in light of much recent writing on nationalism and the politics of identity which sees cultural production, and in particular the novel, as a dominant force in shaping our perceptions of national belonging. ${ }^{13}$

\section{Articulating oppression}

In terms of popular culture, it is undoubtedly Irvine Welsh's novel Trainspotting which is the most widely known example of an author attempting to transcribe the uncompromisingly abstruse accents of Scotland's housing estates. ${ }^{14}$

Underground: a discussion of cultural politics in contemporary Scotland', Etudes écossaises, n 3, 1996, pp. 117-128.

${ }^{9}$ Alasdair GRAY, Why Scots Should Rule Scotland 1997, Edinburgh: Canongate, 1997.

${ }^{10}$ Keith Dixon notes how this does not imply any form of affiliation with the Labour Party. Keith DIXON, 'Writers into battle', p. 165. It can however be noted that in recent years some authors have spoken out in support of the more leftwing Scottish Socialist Party. See Kirsty SCOTT, 'Scotland's red rebellion', The Guardian: Saturday Review, 14/7/2001, p. 2.

${ }^{11}$ See Douglas DUNN, 'Divergent Scottishness: William Boyd, Allan Massie, Ronald Frame', pp. 149-169 in: Gavin WALLACE \& Randall STEVENSON (eds.), The Scottish Novel Since the Seventies (1993), Edinburgh: Edinburgh University Press, 1994.

${ }^{12}$ «L'étude du texte littéraire n'a d'intérêt et n'est, à proprement parler, possible que si ce texte n'est pas isolé d'emblée, s'il n'est pas coupé du réseau socio-discursif dans lequel et sur lequel il travaille. » Marc ANGENOT, «Que peut la littérature ? Sociocritique littéraire et critique du discours social », p. 13 in : Jacques NEEFS \& Marie-Claire ROPARS (dir.), La Politique du texte : enjeux sociocritiques, Lille: Presses Universitaires de Lille, 1992.

${ }^{13}$ See, for example, Timothy BRENNAN, 'The national longing for form', p. 49 in : Homi K. BHABHA (ed.), Nation and Narration (1990), London \& New York: Routledge, 2002.

${ }^{14}$ One must also mention Danny Boyle's film adaptation based on John Hodge's screenplay, which although adding to the novel's iconic status (see the countless re-editions of the novel featuring the film's distinctive orange logo as well as photographs of Ewen McGregor and fellow actors) generally toned down the language of the original work. 
Irvine Welsh's use of multiple autodiegetic narrators who phonetically render their own personal variants of lower class Scottish English or 'urban demotic' is as striking as the often scabrous subject matter. Nevertheless, the debt of such a work towards figures such as Tom Leonard or James Kelman should also be remembered. Leonard and Kelman have been experimenting, respectively in poetry and fiction, with forms of urban demotic since the 1960s. Importantly, they have also sought to theorise the sociolinguistic tensions that become apparent when the non-codified forms of Scottish working class speech, by being elevated to the status of print language, transgress implicit notions of decorum and hierarchy. ${ }^{15}$ Earlier Scottish writers often sidestepped such issues of sociolinguistic propriety by deferentially enclosing authentic, but non-standard, local speech in the inverted commas which circumscribed it as dialogue, thus carefully quarantined from the legitimate literary text with its Standard English narrative voice.

James Kelman in particular has had a profound impact on contemporary Scottish writing. His influence is in part due to his espousal, within the narrative voice, of regionalisms and non-standardised spelling which better convey local particularities of expression and pronunciation, but also by his refusal to countenance the very notion of any language being illegitimate and unfit for literary expression. ${ }^{16}$ This explains his militant rejection of the symbolic way markers - the apostrophes and inverted commas - which, in ordering the text, also establish lines of demarcation between different utterances and their respective levels of language. Kelman's writing is characterised by this disruption of textual conventions: its predilection for rogue capitalisations and absent punctuation marks, its abrupt incipits and endings, its use of a constantly shifting free indirect style which segues between voices, and its radical preciousness which fuses the haughty lexicon of the upper classes with the most disdained four-letter words in the English language. ${ }^{17}$ Simplistically, James Kelman's fiction has been maligned in certain quarters for its excessive use of 'bad language', in particular during the furore over the number of times 'fuck' appeared in his Booker Prize winning novel, How Late it Was, How Late. ${ }^{18}$ These rather patrician attitudes, in their attempts to delegitimise Kelman's literary voice as uncultivated and inauthentic, neither proper English nor Scots, vindicate the author's view of an unspoken axiology underlying the Standard English narrative. ${ }^{19}$ For Kelman, such a construct, rather than being a value-free vehicle for the transmission of ideas, insidiously promotes the world view of a British socio-cultural elite by removing regional or working class expression ${ }^{20}$ from the narrative voice, 'the place where thought and spiritual life exists'. ${ }^{21}$

${ }^{15}$ See, for example, James KELMAN, Some Recent Attacks: Essays Cultural \& Political, Stirling: AK Press, pp. 81-84.

${ }^{16}$ See H. Gustav KLAUS, '1984 Glasgow: Alasdair Gray, Tom Leonard, James Kelman', Etudes écossaises, $\mathrm{n}^{\circ} 2,1993$, p. 38.

${ }^{17}$ H. Gustav KLAUS, ibid., p. 38.

${ }^{18}$ For an example of this see Simon JENKINS, 'An expletive of a winner', The Times, $15 / 10 / 1994$, p. 20

${ }^{19}$ Keith DIXON 'Punters and Smoky Breath: The Writing of James Kelman', Écosse : Littérature et Civilisation, ${ }^{\circ} 9$, 1990, p. 67.

${ }^{20}$ It goes without saying that the two are conflated in the UK. Peter TRUDGILL, Sociolinguistics: An Introduction, London: Penguin, 1974, pp. 18-19.

${ }^{21}$ James KELMAN, Some Recent Attacks, p. 82. 
Scottish fiction now regularly presents such textual tensions and often portrays various forms of linguistic confrontation when the spontaneous native speech of the (often lower class) Scot collides with the culture, institutions or defenders of middleclass, and thus anglicised, diction. ${ }^{22}$ These vignettes play on widely felt Scottish fears about national and class prejudices which assimilate a noticeable Scottish accent or the use of Scots terms with inarticulacy, poor schooling or social inferiority. ${ }^{23}$ The new generation of Scottish writers have resolutely refused to see their own variants of English as substandard and adulterated. In doing so, they have broken with a tradition of authors who, with their eyes set on the metropolitan market, found their natural Scottish expression an inconvenience to be obviated, thus placing a crippling dilemma at the heart of Scottish literary production. ${ }^{24}$ The dissatisfaction with the unchallenged primacy of the centre, as evidenced by authors such as James Kelman, and the subsequent recentring on the specificities of local experience, can be seen as preceding, in linguistic and cultural terms, the Home Rule movement and the achievement of political devolution in the late $1990 \mathrm{~s}^{25}$

\section{Transformation as degradation}

If the thematic preoccupations of contemporary Scottish fiction tend to revolve around the dissatisfactions of post-industrial society, this does not signal the nostalgia for a bygone industrial age or the purely urban focus that has sometimes been suggested. Authors such as Iain Banks, Duncan McLean or Alan Warner, for example, depict rural, coastal or Highland settings which, despite coming into contact with an often destabilising modernity, refuse to hark back to the supposed purity of a preindustrial Celtic dawn. On one level, Scotland's recent socioeconomic history has simply come to form an obvious backdrop for much of its fiction. The rapid deindustrialisation is often connoted negatively, reflecting T.M. Devine's comments about the disturbing speed of this phase of Scottish history. ${ }^{26}$ But, more surprisingly perhaps, so too are other related phenomena: Glasgow's slum clearance programmes, the gentrification of old industrial sites renovated as residential developments, or the growing importance of the oil, retail and tourism sectors.

For example, the novels The Busconductor Hines by James Kelman, or Swing Hammer Swing! by Jeff Torrington both feature narrators surrounded by the obliteration of entire neighbourhoods as part of Glasgow's redevelopment in the

${ }^{22}$ See for example the trial scene in Irvine WELSH, Trainspotting (1993), London: Minerva, 1996, pp. 165-167.

${ }^{23}$ See Christie Leigh MARCH, 'Interview with Janice Galloway, Glasgow, March 21, 1999', Edinburgh Review, n¹01, 1999, p. 91.

${ }^{24}$ This notion, inherited from Edwin Muir, implied that any Scottish author unwilling to abandon his natural speech in favour of Standard English was destined to fail. See Keith DIXON, 'La Langue vernaculaire comme enjeu idéologique dans la littérature écossaise contemporaine : Edwin Muir et la Renaissance de l'Entre-Deux-Guerres', Écosse : Littérature et Civilisation, $\mathrm{n}^{\circ} 5-6,1986$, p. 188. The question of a potential handicap was still being debated in the early 1980s when the Scottish Chapman Magazine devoted an entire issue to this theme. Chapman Magazine, 'The State of Scotland - A Predicament for the Scottish Writer?', vol. VII, n³5-36, July 1983.

${ }^{25}$ See Keith DIXON, 'Notes from the Underground', p. 118.

${ }^{26}$ T.M. DEVINE, The Scottish Nation, p. 594. 
1960s. The presentation of an initial period of destructive change sets the tone for fiction set in the next three decades when the shipyards, steelworks, coalmines and car production plants had all but disappeared from Scotland. James Meek insists on the abruptness of the economic transition with hybrid images where the new cannibalises the old to produce a sham of progress and modernity. Such figures of mutation suggest not the transition, however disruptive, from one stable era to the next, but the entry into the next level of capitalism, where ceaseless change and 'creative destruction' ${ }^{27}$ are the new norm. In McFarlane Boils The Sea, it is the hollowed-out hulk of a ship, the final product of a closing yard, ignominiously towed upstream to become a floating restaurant for the well-to-do (p. 37); in Drivetime, the insane plans for an abandoned mineshaft to be transformed into a subterranean shopping centre where shoppers will crawl along darkened tunnels pushing trolleys full of groceries (p. 269). Ian Rankin's popular detective series harbours similar concerns about economic transformation. Detective Rebus hails from formerly coal-rich Fife, but the region's industrial past has been symbolically erased from the landscape as if in an act of collective denial:

The mines around here were all worked out, had been since the $1960 \mathrm{~s}$. Now money had appeared from somewhere, and the long-smouldering bings were being levelled, their mass used to fill the chasms left by surface mining. The mine buildings themselves were being dismantled, the landscape reseeded, as though the history of mining in Fife had never existed. (Hide \& Seek, p. 161)

It is into this void that new money flows as a dangerous, corrupting force: the Aberdeen-based oil industry, for example, is assimilated not with the optimism of the 1970s nationalist campaign, but with increased greed and materialism, as well as the substantial oil revenues which were generated for central government in the 1980s:

[The oil industry] kept Maggie Thatcher in power. Oil revenue paid for all those tax cuts. Oil revenue paid for the Falklands War. Oil was pumping through the veins of her whole fucking reign. (Black \& Blue, p. 212)

In the west Highland port of Oban, Alan Warner's eponymous anti-hero Morvern Callar, a supermarket shelf stacker, defines the new (predominantly female) generation who work in unfulfilling, low-paid employment in the retail sector. The transition from one era to another in terms of generation and gender - Morvern's foster father is a leftwing rail worker on the verge of retiring - updates that of the Chris / Ewan transition, which symbolised Lewis Grassic Gibbon's rural Scotland being drawn irrevocably into the industrial age. ${ }^{28}$ Tourism, too, is treated with suspicion, due to its ability to create powerful mythologies which sanitise or deform the past. Duncan

${ }^{27}$ Joseph SCHUMPETER, Capitalism, Socialism and Democracy (1942), New York: Harper, 1975, pp. 82-85.

${ }^{28}$ For the Chris / Ewan transition, see Roderick WATSON, 'Maps of Desire: Scottish literature in the Twentieth Century', p. 299 in : Thomas DEVINE M. \& Richard J. FINLAY (eds.), Scotland in the $20^{\text {th }}$ Century, Edinburgh: Edinburgh University Press, 1996. 
McLean touches on these issues in Blackden with the ironic figure of an optimistic postcard manufacturer whose collection, entitled The Sun Sets on the Great Scottish Industries!, features images such as the Ravenscraig steel plant whose closure marked one of the peaks of leftwing mobilisation in the 1980s (p. 124).

The personal response in the context of industrial decline and post-industrial disaffection is often described in terms of flight from Scotland. Novels such as The Busconductor Hines, How Late it Was, How Late, Swing Hammer Swing!, Morvern Callar, Blackden, and Trainspotting all involve a central character contemplating selfimposed exile, whether realised or not, to destinations such as the Commonwealth, the USA, or, latterly, countries of the EU. These individualistic and often desperate solutions, although repudiating a continued existence within Scotland, do not necessarily invalidate the country's fundamental viability. Instead, they can be collectively read as narratives which repeatedly insist on the unsustainability of a status quo which generates abstract feelings of helplessness and oppression.

For those that remain, the long-feted myth of Scottish egalitarianism and clanlike community seems to have been eroded, even in the writing of William Mcllvanney, which obdurately salutes its humanist ideals even in their passing. What is left is the constant threat of atomisation and alienation, as presented in novels like The Big Man where McIlvanney's depiction of a bare-knuckle fight reads as a metaphor for a dehumanised society. In a context where mass unemployment is the bedfellow of rampant materialism, the prize fight is an opportunity for swift financial gain. However, as a quintessence of competitive individualism, the brutal confrontation also risks stripping the contenders of their humanity. Irvine Welsh's Trainspotting operates along similar lines, with heroin addiction reducing the central characters, once boyhood friends, to essential consumers, suppliers, competitors and, in one memorably corporate phrase 'jist associates' ${ }^{29}$ Interestingly, the descriptions of trafficking and addiction often borrow the language of neo-liberalism, ${ }^{30}$ thus showing this nihilistic subculture to be subsumed by the dominant discourses it thought it had eluded. ${ }^{31}$

The vibrant reaffirming of Scottish modes of expression in such novels is hard to dissociate from class, and consequently political, considerations. In addition to their renewed interest in Scottish working class voices, what links many of these novels is their sense of desolation accompanying the transition from heavy industry to a service economy, and their cry of revolt as Thatcher's Britain becomes more coldly materialistic and individualistic. In certain works the underlying opposition to Thatcherism, and to the perceived injustice of a British constitutional system blamed for having allowed the Conservatives to govern in Scotland without a popular mandate, becomes central. In these more overtly political novels, the hostility to

${ }^{29}$ Alan FREEMAN, 'Ghosts in Sunny Leith: Irvine Welsh's Trainspotting', p. 257 in : Susanne HAGEMANN (ed.), Studies in Scottish Fiction: 1945 to the Present, Frankfurt: Peter Lang, 1996.

${ }^{30}$ See Irvine WELSH, Trainspotting, p. 310, p. 319, p. 327, p. 332, p. 339.

${ }^{31}$ Cairns CRAIG, The Modern Scottish Novel, Edinburgh: Edinburgh University Press, 2002, p. 97. 
specific policies becomes ever harder to disassociate from the consequent need for Scottish autonomy or independence.

\section{A question of representation}

The novels 1982 Janine (Alasdair Gray), The Bridge (Iain Banks) or Electric Brae (Andrew Greig) articulate their rejection of the Conservative domination of Scotland around certain recurrent motifs such as unaccountable government or nuclear annihilation. Alasdair Gray's novel, in contrast to its narrator's salacious imaginings, uses images of feminine purity to personify Scotland as an idealised mother, both virginal and fertile (p. 281). But this fecund, female Scotland is also violated and re-imagined as a barren atomic wasteland whose population is to be quarantined from the rest of the UK following a Soviet strike on the UK and US nuclear missile bases sited there (pp. 134-135). Despite the novel's parasitical paratexts which problematise the notion of authoritative, narrative voice within the novel, ${ }^{32}$ thus simultaneously undermining its own pamphleteering tendencies, 1982 Janine treats such questions in essentially nationalist terms. The reason why 'Scotland is wired for war' (p. 134) in the first place is explained by the narrator in the language of colonial misrule:

Apart from a handful of landowners and clergymen the local folk do not want [the nuclear missile bases] but no government need be moved by the wishes of the northern native, especially not the Gaelic native. (p. 134)

Continuing the thematic opposition between sterility and fertility, it is a nationalist friend of the narrator's (significantly deceased) who would have been the 'yeast' necessary to see a feckless, inert Scotland return to life (p. 108). The narrator meanwhile berates the cowardly impulses of a country too ready to kowtow to their superiors, referring to Scotland as 'a nation of arselickers' (p. 65) ${ }^{33}$ Tellingly, the same term is then used in a constitutional context when it refers to those Scottish MPs who 'see the problems of Scotland in a totally different light when [they] get to Westminster' (p. 66). The ever-present theme of sexual domination returns the otherwise hackneyed insult to a telling metaphor of wilful corporal subservience, the act itself, in its anality, again symbolically turned away from the vigorously fecund.

The narrative structure of The Bridge is that of the slow rise to consciousness (both political and physiological) of a comatose entrepreneur whose conspicuous wealth and business dealings within the militaro-industrial complex have compromised his former socialist ideals. The novel alternates science fiction and social realism with the latter ultimately proving to contain the former. Similarly to the frantic pornographic daydreaming in 1982 Janine, which allows Gray's narrator to momentarily avoid 'goading [himself] into a FRENZY' about the handling of the

${ }^{32}$ For a full study on this aspect of Gray's work see Marie Odile PITTON-HEDON, Alasdair Gray : Marges et effets de miroirs, Grenoble : Ellug, 2004.

${ }^{33}$ A similar cowardice is explored in William McIlvanney's poem 'The Cowardly Lion', which deals specifically with the aftermath of the 1979 referendum. William MCILVANNEY, Surviving the Shipwreck, Edinburgh: Mainstream, 1991, p. 22. 
1979 referendum (p. 66), the disturbing metadiegetic world of the endless Bridge is a means by which the narrator has escaped his own ideological complicity in 'Thatcher's Britain and Reagan's world' (p. 283). It is the two leaders' personal relationship which particularly exacerbates fears in the Cold War context, with the nuclear threat written in terms of an Anglo-American alliance between reactionary governments, neither of which holds a mandate in the territory where key nuclear bases are situated. ${ }^{34}$

Nevertheless, beyond a distaste for Thatcherite politics, any clear political message is once again destabilised in the novel. A self-deprecating tone mocks the narrator's tardy adoption of a nationalist problematics and shows Scotland's history as a series of repeated dislocations:

Athens, Rome, Alexandria; they had libraries when all we had were hill forts; not savages, but not civilised either. By the time we were ready to play our part it was already too late; we were always too soon or too late, and the best things we've done have been for other people.

Well, sentimental Scottishism, he guessed. What about class consciousness rather than nationalism? Well, indeed. (p. 263)

Such desynchronisation ${ }^{35}$ does little to suggest a pre-ordained path, a nationalist teleology. Unlike the ordered strata of the novel's narrative sections whose geological names convey an ineluctable rise to the surface, Scotland's history appears as an endless cycle of missed opportunities. Instead, these repetitions mimic the interminable nature of the Bridge-world of the novel's fantasy sections and indeed also the curves of The Bridge's real life model over the River Forth, which, due to the task of painting its great size, has been adopted in popular parlance as a metaphor for unending, thankless toil. ${ }^{36}$

In a device shared with both 1982 Janine and Andrew Greig's Electric Brae, the personal development of Banks' central character is charted against events in Scotland's recent political history, in particular the failed devolution referendum of 1979 and the Conservative's subsequent general election victories. The frequency with which the year 1979 appears in Scottish novels as a year of particular import seems to confirm the view that the referendum debacle led to years of painful reappraisal, not only as regards Scotland's position within the UK, but also concerning the Scots' notions of identity and self-worth. ${ }^{37}$ Evocations of the referendum stand out in these novels for their use of the language of trickery and deceit, seeking to portray the moment as a key instance of anti-Scottish conspiracy

\footnotetext{
34 'Scotland voted for Labour, with the SNP a close third. What it actually got was the right honourable Margaret Thatcher, M.P. He shook his head again. "Oooohh, shit." Iain BANKS, The Bridge (1986), London: Abacus, 1996, p. 241. “"Why don't I get a vote?” he raged. "My Dad lives spitting distance from Coulport, Faslane and the Holy Loch; if that buffoon's liver-spotted finger hits the button my old man's dead; probably all of us are [...] so why the fuck don't I get a vote? "' Iain BANKS, ibid., p. 246.

${ }^{35}$ A similar view of Scottish history is analysed in Cairns CRAIG, Out of History, p. 32.

${ }^{36}$ See Iain BANKS, The Bridge, p. 283.

${ }^{37}$ Manfred MALZAHN, Aspects of Identity: The Contemporary Scottish Novel (1978-1981) as National Self-Expression, Frankfurt: Peter Lang, 1984, p. 3.
} 
at the hands of the British Establishment. In 1982 Janine, as the narrator berates the famous $40 \%$ rule which changed 'the usual sporting rules for electing a new government' and saw a slight majority equated with a 'no' vote, his reasoned tone degenerates into vituperations about 'fucking politics' (p. 66), thus reiterating the novel's key sexual metaphor: "Scotland has been fucked. I mean that word in the vulgar sense of misused to give satisfaction or advantage to another". (p. 136)

In The Bridge, the tone is one of mock ebullience: 'The Fabulous Make-YourMind-Up Referendum was, effectively, pochled - rigged, in English' (p. 239). As if to hint at the backlash to come, the use of a rare dialectal borrowing underlines Scotland's cultural distance from the metropolitan centre. In Electric Brae, Andrew Greig's dysfunctional micro-community of friends and lovers begins in March 1979 with the first cigarette smoked since the referendum, just as a Party Political Broadcast is symbolically switched off from a pub television (pp. 10-11). But here, as is common in Scottish fiction, politics refuses to be silenced. By using the general election victories of the Conservatives in the 1980 s to structure the characters' development, the novel posits the pervasive influence of politics on all existence, whether the public spheres of education and art, or the intimate spheres of friendship, paternity and sexual identity. In this largely rural novel, the menace of nuclear annihilation, again associated with Thatcher and Reagan's Cold War rhetoric and the proximity of missile bases, ridicules a previous generation's notion of the permanence of the land (p. 95). ${ }^{38}$ In national terms, the Westminster-based electoral system is described as a metaphorical football match between Scotland and England in which the Scots can but lose (p. 102). Union has been replaced by ritualised confrontation and defeat.

This is not an example of the malignant self-flagellation that commentators so enjoy attributing to the Scots. ${ }^{39}$ Cultural identity in the novel is defined in terms of growing constitutional exasperation at such repeated failure and at the iniquity of this situation. Opting for a scientific metaphor that goes beyond the more commonplace notion of Thatcher as a catalyst for nationalism, the results of Thatcher's repeated elections triumphs are likened in Greig's novel to a litmus test in which the Scots repeatedly, steadfastly come out 'redder' than Tory-blue England (p. 222). Scotland's cultural difference is thus reasserted in terms of its continued espousal of egalitarian, leftwing values, at odds with Middle England's Thatcherism. The insistence on real world psephological data seeks to argue Scotland's fundamental difference in substantiated, empirical terms, but the novel, in lamenting the loss of a 'Scottish way' (p. 207), a supposedly innate form of egalitarianism, cannot help straying into mythology. In his defence of such humanist values, the novel's key politicised character, Graeme, abandons a constitutionally helpless Labour party for the SNP, but, once again, the richness of the narrative text prevents it from becoming a roman à thèse clamouring for independence. One dominant mode of Scottishness in the novel is that of a dour and unyielding masculinity, and the death of Graeme (a climber) in the disintegration of a rock pillar known as an

\footnotetext{
${ }^{38}$ Compare with Lewis GRASSIC GIBBON, Sunset Song (1932), London: Penguin, 1986, p. 97.

39 'With so many defeats to contend with the Scots have gradually come to regard themselves as born losers. The national penchant for pessimism relates to habitual defeatism.' Alan BOLD, Modern Scottish Literature, London \& New York: Longman, 1983, p. 1.
} 
'Old Man' plays out a form of self-emasculating patriarchy. As politics and private life are intimately bound up in the novel, the suggestion has to be that any move towards a political solution such as independence will be futile if Scotsmen do not first get their own house in order.

Whereas Duncan Thaw in the novel Lanark clearly articulates the case for Scottish Home Rule before an imagined House of Commons, arguing that 'the vaster the social unit, the less possible is true democracy' (pp. 288-289), such open pronouncements of the nationalist case are, notwithstanding Alasdair Gray's work, rather rare in the Scottish fiction of the 1980s and 1990s. Rather, we see that, as in Iain Bank's thriller Complicity, ${ }^{40}$ or in Christopher Brookmyre's Quite Ugly One Morning, narratives which unselfconsciously attack Thatcherite principles and values as the vectors of shallow, self-serving materialism can appeal, a contrario, to the powerful myth of Scotland's inherent fairness and decency. ${ }^{41}$ The unspoken conclusion is that the failure of the 1978 Scotland Act to modify the UK constitution allowed an unrepresentative government to force alien policies onto an unwilling Scots populace.

\section{National chemistry}

One of the highest-profile cultural models to be associated with Scottish writing in the 1990s was that of the 'Chemical Generation' of writers associated with drug-taking and its depiction in literature. Although sometimes applied to writers such as Alan Warner, the term is used principally in relation to Irvine Welsh, whose fiction was indeed actively marketed with reference to the term, ${ }^{42}$ and whose tales of heroine addiction, casual cannabis smoking and the rave culture of ecstasy are set in a contemporary context where recreational drug use has become prevalent. Nevertheless, the notion of a generation defined by its reliance on 'chemicals', i.e. narcotics, also suggests a youth who, through apathy or desperation, have retreated to a permanently drugged state which anesthetises any remaining regard for politics they might have had. The implications for both national and nationalist politics are important. Indeed, Trainspotting, with its extreme breakdown of community, has been described as a novel which illustrates how the very concept of the nation is an anachronism in the postmodernist age. ${ }^{43}$

A close reading of Trainspotting, however, calls into question the post-national character attributed to this work, and indeed to much of Scotland's recent fiction. ${ }^{44}$

\footnotetext{
40 'If that book [Complicity] reeks of hatred for the Tories, and the odious, corruptionsaturated, greed-obsessed culture they have brought to fruition in these isles over the last one and a half decades then it has not all been in vain [...]' Iain Banks quoted by Richard TALLARON, 'Iain Banks', Études écossaises, n³, 1996, pp. 143-144.

41 'Few myths are more powerful and prevalent in and about Scotland than that it is a more egalitarian society than England [...]' David McCRONE, Understanding Scotland: The Sociology of a Stateless Nation, London - New York: Routledge, 1992, p. 88.

${ }^{42} \mathrm{See}$, for example, the subtitle for Ecstasy which refers to itself as 'Three tales of Chemical Romance'. Irvine WELSH, Ecstasy (1996), London: Vintage, 1997, inner title page.

${ }^{43}$ Andrew MONNICKENDAM, 'Lost Causes: national identity and postmodernism', Études écossaises, n³, 1996, p. 105.

${ }^{44}$ This charge is also made by Douglas GIFFORD, The Dear Green Place?: The Novel in the West of Scotland, Glasgow: Third Eye Centre, 1985, p. 8.
} 
Firstly, rather than a novel which has disengaged from politics, its reworking of neoliberal discourses, which are then applied to the underworld trafficking of heroine, suggests a text with a heightened awareness of political irony. Here, as elsewhere in Welsh's fiction, escapist drug use is presented in the language of political disenfranchisement, with the young alienated as much by mainstream politics as by the economic system. ${ }^{45}$ Secondly, rather than one which disputes or disregards the validity of the nation in general, and Scotland's place in the UK in particular, Trainspotting is a novel which remains quite obsessed with these concepts, particularly when they are viewed through the prism of the Irish question.

The mixed Catholic / Protestant parentage of Mark Renton, the central character and chief narrator, problematically links him to both Unionism and to the historic Irish Republicanism whose heroes Renton and friends celebrate in song for Hogmanay (pp. 45-46). Renton, in his oft quoted 'Ah hate the Scots' speech (p. 78), condemns the Scots as 'wretched, servile, miserable, pathetic trash' for having been 'colonised' by the English, the 'effete arseholes' and 'wankers' who now rule the country. This is not mere literary posturing, a nod to the recognised motif of the anti-Scottish tirade. The sexual imagery used - similar depictions can be commonly found: one need think only of the film Braveheart - insists that accepting an English overlord is all the more shameful given that the latter's femininity and onanism leaves little excuse but pusillanimity to explain the supposedly vigorous Scots' failure to remove them. ${ }^{46}$ The Scots, 'shat intae creation', are thus indeed conceived of as a collective entity, but one which is soiled and still-born, a disgraced nation entirely devoid of honour or vitality. While situating Scotland in a debatable problematics of colonialism, the passage, through its anal and sexual imagery, reactivates the same opposition of sterility and fecundity already seen in 1982 Janine as Jock bemoans Scotland's domination through the Westminster Parliament. In Renton's speech, the language of shame and self-hate perfectly illustrates what Tom Nairn describes as 'national nihilism': not the absence of national sentiment, but the negative emotions associated with Scotland's voluntary renunciation of statehood in exchange for subordinate participation in Union and Empire. ${ }^{47}$ Meanwhile, Renton's Catholic heritage exacerbates his frustrated nationalism as he contemplates how 'The Irish hud the bottle tae win their country back, or at least maist ay it' (p. 190). The irony is compounded by the fact that his brother, the good Scottish soldier, is blown up by the IRA while defending British rule in Ulster (pp. 209-211). Thus Renton's spurious claim that he has 'never felt a fuckin thing aboot countries, other than total disgust. They should abolish the fuckin lot ay them' (p. 228) should perhaps not be read too quickly as post-national nihilism, but as the desperation and shame of absent or quietist nationalism, made more acute by the

\footnotetext{
45 'I'm thinking, what can I do, really do for the emancipation of working people in this country, shat on by the rich, tied into political inaction by servile reliance on a reactionary, moribund and yet still unelectable Labour Party? The answer is a resounding fuck all. [...] I think I'll stick to drugs to get me through the long, dark night of late capitalism.' Irvine WELSH, Trainspotting, p. 240.

${ }^{46}$ See also Irvine WELSH, ibid., p. 228.

${ }^{47}$ Tom NAIRN, After Britain: New Labour and the Return of Scotland, London: Granta, 2000, pp. 99-103.
} 
Irish precedent, which shows that the British state could indeed be redrawn, if the collective will were there.

\section{There shall be a Scottish parliament...}

It is clear that a dominantly left-leaning Scottish literature was energised by its opposition to the period of Conservative Westminster rule with writers depicting themes such as social disintegration, economic destruction, constitutional iniquity and nuclear menace as the egregious effects of Thatcherism. A sense of loss and degradation is thus associated with the period of Conservative domination, with Margaret Thatcher in particular operating as a powerful negative pole against which a Scottish identity, in its degradation, seeks to define itself. ${ }^{48}$ Even its Scottish working class inflexions contrast markedly with a Conservative Party perceived as a thoroughly English phenomenon in terms of diction as well as support, ${ }^{49}$ and whose strong centralising tendencies and own brand of Anglo-British nationalism were felt to be hostile to Scottish specificities. Although charged by some with complacently portraying a culture of failures and victims, ${ }^{50}$ the Scottish fiction of the 1980 s and 1990 s is marked not by its pessimism, but by its revolt. Socially and politically aware, it is a literature which constantly rails against the injustices of the status quo, but which also, true to its nature, avoids sententious prescriptions, nationalist or otherwise. It is a literature which believed change possible and which believed itself, not politicians or political parties, to be the primary agent of change. Michael Keating argued in 1997 that Scottish culture's new-found confidence was - as the country pondered its place in the United Kingdom and in Europe - strengthening not only the sense of a distinct national identity but also, indirectly, the nationalist cause. $^{51}$ (The fact that devolution and not independence became a reality shortly afterwards does not damage this analysis, on the contrary.) What is certain is that before 1999, in the absence of the country's own distinct political institutions, Scottish literature served as an important forum for debate on the condition and identity of modern Scotland. Thus when a group of writers were asked what influence the new Scottish Parliament would now have on their writing, authors such as Janice Galloway, AL Kennedy or Duncan McLean all chose to turn the question on its head. In the words of Duncan McLean:

What influence will the Scottish Parliament have on Scottish Writing? Very little. The influence will be the other way around. After all, hasn't Scottish writing been one of the major causes in bringing the Scottish Parliament into existence? When the politicians were faffing about, infighting, backhanding etc. from 1979 to 1998 [sic] and basically doing bugger all to provide some kind of self-determination for the

48 Gilles LEYDIER, «L'Écosse et la dévolution: D’un référendum à l'autre », Études écossaises, n ${ }^{\circ}$, 1998, p. 47.

49 'Modern Conservatism spoke overwhelmingly with a Southern English Voice.' David McCRONE, Understanding Scotland, p. 173.

50 See Allan MASSIE, 'Must all our new cultural icons remain mired in this working-class mythology?', Daily Mail, 20/8/1998, p. 11.

51 Michael KEATING, Les défis du nationalisme moderne: Québec, Catalogne, Écosse, Montreal: Presses Universitaires de l’Université de Montréal, 1997, p. 218. 
people of Scotland, it was the writers (not alone amongst the artists, but possibly leading from the front) who articulated a sense of Scottish identity, of Scottish values, of Scottish concerns. They weren't necessarily leading the people in doing all this: they just shared the population's taking-for granted of Scotland's right for more selfdetermination, and wrote with that assumption in mind. And gradually the politicians started to catch up. There's been a parliament of novels for years. The parliament of politicians is years behind. ${ }^{52}$

Since 1999, Scottish fiction has seemingly begun to turn away from its preoccupation with the cultural politics of contemporary Scotland, as authors broaden their range and scope in the exploration of other eras and settings. That this has happened does not, however, mean that writing from a Scottish perspective has become any less valid. It has perhaps become less urgent though. The parliament of novels, by formulating popular opposition to Conservative politics and Westminster rule, helped usher in a new constitutional settlement. Following the establishment of Holyrood, the arguments, in both literature and politics, over the legitimacy of a Scottish perspective have seemingly been settled.

\section{Cited fictional works, 1979-1999}

BANKS, Iain, The Bridge (1986), London: Abacus, 1996. , Complicity (1993), London: Abacus, 1994.

BROOKMYRE, Christopher, Quite Ugly One Morning (1996), London: Abacus, 1997.

GRAY, Alasdair, Lanark: A Life in Four Books (1981), London: Paladin, 1989. , 1982 Janine, London: Jonathan Cape, 1984.

GREIG, Andrew, Electric Brae, Edinburgh: Canongate, 1992.

KELMAN, James, How Late it Was, How Late, London: Secker \& Warburg, 1994. , The Busconductor Hines (1984), London: Everyman, 1985.

McILVANNEY, William, The Big Man (1985), London: Sceptre, 1990.

McLEAN, Duncan, Blackden (1994), London: Minerva, 1995.

MEEK, James, McFarlane Boils The Sea, Edinburgh: Polygon, 1989. , Drivetime, Edinburgh: Polygon, 1995.

RANKIN, Ian, Hide \& Seek (1990), London: Orion, 1998. , Black \& Blue (1997), London: Orion, 1998.

TORRINGTON, Jeff, Swing Hammer Swing! (1992), London: Minerva, 1994.

WARNER, Alan, Morvern Callar (1995), London: Vintage, 1996.

WELSH, Irvine, Trainspotting (1993), London: Minerva, 1996. , Ecstasy (1996), London: Vintage, 1997.

\footnotetext{
52 Duncan McLean quoted in 'Poets' Parliament' (texts by John BURNSIDE, Janice GALLOWAY, A.L. KENNEDY et al.), Edinburgh Review, n¹00, 1999, p. 74.
} 